\title{
PERAN KELUARGA DALAM UPAYA PENCEGAHAN ADIKSI PORNOGRAFI PADA ANAK USIA SEKOLAH DASAR
}

\author{
Rifqa Tsani Qurrota Ayyun, Elly Malihah \\ Universitas Pendidikan Indonesia \\ Email:rifqayyun@student.upi.edu,ellyms@upi.edu
}

\begin{abstract}
Abstrak
Seiring dengan perkembangan teknologi dan informasi, saat ini tidak dapat dipungkiri bahwa pornografi menjadi suatu permasalahan yang telah menyentuh kehidupan setiap orang tidak terkecuali anak yang masih berusia Sekolah Dasar. Sebagai pihak yang memiliki tugas penting bagi tumbuh kembang anak, keluarga memiliki peran dan fungsi yang tidak bisa dihilangkan atau lepas dari kehidupan anak bahkan sampai mereka berusia dewasa. Penelitian ini memiliki tujuan untuk mendapatkan penjelasan dan gambaran mengenai peran keluarga dalam suatu upaya pencegahan adiksi pornografi kepada anak usia Sekolah Dasar di Kelurahan Derwati Kecamatan Rancasari Kota Bandung. Desain penelitian ini menggunakan pendekatan kualitatif dengan metode studi kasus. Pada pelaksanan penelitian ini pengumpulan data yang digunakan adalah dengan teknik observasi partisipan, wawancara secara mendalam, studi dokumentasi dan studi literatur. Objek pada penelitian ini adalah orang tua yang memiliki anak usia Sekolah Dasar (6-12 tahun) sebagai informan pokok dan anak-anak dalam keluarga tersebut sebagai informan pangkal. Adapun hasil dalam penelitian ini menunjukan bahwa: (1) Orang tua melakukan sosialisasi sebagai pengetahuan awal kepada anak seperti informasi mengenai bahaya pornografi dan pendidikan seks. (2) Terdapat berbagai faktor baik secara internal maupun eksternal yang dapat menyebabkan terjadinya adiksi pornografi pada anak usia Sekolah Dasar. (3) Penanggulangan dilakukan kepada anak yang telah terpapar pornografi untuk mencegah anak dari adiksi pornografi. Terdapat berbagai upaya yang dilakukan oleh keluarga untuk melindungi dan mencegah setiap anggota dalam keluarga terutama anak dari bahaya pornografi. Dari setiap upaya yang dilakukan oleh keluarga hal ini tidak terlepas dari kendala-kendala yang muncul pada saat proses pencegahan tersebut.

Kata kunci: $\quad$ anak, adiksi pornografi, keluarga
\end{abstract}

\section{PENDAHULUAN}

Perkembangan teknologi dan informasi dewasa ini berkembang semakin cepat. Melalui akalnya, manusia menciptakan dan mengembangan segala hal yang mereka inginkan untuk menyelesaikan masalah dan memberikan kemudahan dalam kehidupannya. Seiring dengan berkembangnya teknologi, penggunaan gadget dan Internet di Indonesia terus berkembang. Bahkan Indonesia masuk urutan tiga besar sebagai negara dengan pengguna internet terbanyak.

Bagi masyarakat kita saat ini, perkembangan teknologi dan infosi dapat memudahkan setiap orang untuk menjalin hubungan dari berbagai negara dan mengetahui lebih jauh orang-orang yang berada jauh dari mereka. Setiap orang dapat mengakses berbagai situs yang menambah pengetahuan mereka. Salah satu upaya untuk memuaskan rasa ingin tahu yang dimiliki tersebut saat ini tidak jarang orang membuka situs yang mengandung unsur pornografi dan dilakukan secara terang-terangan ataupun hanya sekilas karena ketidaksengajaan. Saat ini kemudahan mengakses internet membuat orang-orang yang sebelumnya tidak memiliki tujuan utama untuk membuka situs pornografi secara sengaja justru semakin mudah. Kemudahan mengaskses internet dengan bebas menjadi kehawatiran yang besar bagi para orang. Seperti handphone pribadi ataupun milik orang tua dan gadget lainnya yang mendukung seseorang untuk mengakses segala hal termasuk hal-hal yang berkonten pornografi. Menurut E. Schaefer dan Foy (1997, hlm. 212) bahwa "pornografi menampilkan seks dari orangorang yang "sakit" sebagai model prilaku yang bejat dan kejam sebagai hal yang wajar".

Dari hasil sensus yang dilakukan oleh Badan Pusat Statistik (BPS) terdapat 83,99 juta anak di Indonesia yang berusia 0-17 tahun. Mereka adalah digital native atau penduduk dunia digital, karena mereka sudah akrab dan biasa dengan perkembangan teknologi maka ini menjadi hal yang tidak asing bagi anak-anak. Kehidupan mereka dikelilingi dengan berbagai macam 
kecanggihan teknologi yang mampu membantu kehidupan mereka. Perkembangan teknnologi saat ini tidak melihat batasan usia atau jenis kelamin. Laki-laki, perempuan, anak-anak, orang tua semua bisa menggunakan internet dan memanfaatkan perkembangan teknologi yang terus berkembang.

Berdasarkan hasil penelitian yang dilakukan oleh Yayasan Kita dan Buah Hati, tercatatat 92\% anak usia Sekolah Dasar pernah melihat hal-hal yang memiliki unsur pornografi. Survey tersebut dilakukan pada 2.500 anak Sekolah Dasar di Jakarta. Berdasarkan penelitian tersebut, didapatkan infromasi bahwa sebesar $47 \%$ anak mengakses situs porno dirumah, $23 \%$ di tempat umum, dan $15 \%$ di sekolah. Rumah yang seharusnya menjadi tempat yang aman dan terkontrol, ternyata menjadi tempat yang paling besar presentasenya bagi anak untuk mengakses situs pornografi. Menurut Talukder (Kastlemen, 2016, hlm. 23) ia menjelaskan bahwa "remaja dan anak-anak lebih rentan terhadap gambar-gambar yang memiliki unsur pornografi dikarenakan otak anak-anak dan remaja masih belum sempurna". Otak anak-anak yang sering terpapar pornografi dapat meenyebabkan dirinya kecanduan terhadap pornografi dan memiliki gangguan emosi. Paparan pronografi memiki dampak negatif bagi perkembangan anak bukan hanya pada aspek afektif saja, tetapi juga pada prilaku anak.

Anak yang sering terpapar pornografi dapat menjadi pemicu terjadinya kecanduan terhadap pornografi. Adiksi terhadap hal yang bermuatan pornografi merupakan suatu kegiatan atau keinginan yang memiliki dampak negatif, karena dapat mengubah struktur dan fungsi orang yang menjadi pecandunya (Kartinah, 2011). Pornografi saat ini menjadi hal yang sangat diperhatikan oleh setiap lapisan masyarakat. Menurut Dr. Elisa Tandiono kecanduan pornografi memiliki pengaruh yang sama dengan narkoba terhadap otak, paparan pornografi membuat beberapa neurotransmiter yang dilepaskan menimbulkan kecanduan (Kartinah, 2011).

\section{METODE PENELITIAN}

Penelitian ini menggunakan pendekatan kualitatif dengan metode studi kasus. Penelitian dilakukan di Kelurahan Derwati Kecamatan Rancasari. Pada penelitian ini terdapat informan yang berjumlah 16, yang terdiri dari empat keluarga. Informan pokok dalam penelitian ini adalah orang tua, yang menjadi informan pangkal adalah anak-anak yang berusia Sekolah Dasar (612 tahun) dalam keluarga tersebut. Adapun yang menjadi informan pendukung adalah anak yang berusia lebih dewasa dari anak usia Sekolah
Dasar. Pihak-pihak tersebut memiliki informasi yang diperlukan peneliti untuk dapat menjelaskan permasalahan yang telah dirumuskan. Hasil penelitian yang diperoleh menggunakan teknik pengumpulan data dengan observasi, wawancara mendalam, studi dokumentasi dan studi literatur.

\section{HASIL DAN PEMBAHASAN}

Berdasarkan hasil penelitian yang diperoleh, setiap keluarga melakukan upaya preventif kepada anak agar terhindar dari kecanduan pornografi dengan memberikan informasi kepada anak menggunakan video yang memiliki visual menarik. Kemudian keluarga menginformasikan kepada anak mengenai pendidikan seks. Sosialisasi yang dilakukan kepada anak di Kelurahan Derwati Kecamatan Rancasari mengenai pendidikan seks masih hanya sebatas anggota tubuh yang boleh dan tidak boleh dilihat. Secara garis besar, pendidikan seks diberikan sejak usia dini (dan pada usia remaja) dengan tujuan sebagai berikut (Reiss dan Halstead, 2006, hlm. 275-307) :

a. Membantu anak untuk mengetahui topiktopik biologis seperti pertumbuhan, masa puber, dan kehamilan;

b. Mencegah anak-anak dari tindak kekerasan;

c. Mengurangi rasa bersalah, rasa malu, dan kecemasan akibat tindakan seksual;

d. Mencegah remaja perempuan di bawah umur dari kehamilan.

e. Mendorong hubungan yang baik;

f. Mencegah remaja di bawah umur terlibat dalam hubungan seksual (sexual intercourse); Mengurangi kasus infeksi melalui seks;

g. Membantu anak muda yang bertanya tentang peran laki-laki dan perempuan di masyarakat.

Memberikan pengetahuan mengenai seks yang lebih luas dapat membantu anak memiliki kepribadian yang sehat secara psikis dan fisik.

Keluarga merupakan suatu lembaga yang memiliki peran penting dalam pencegahan adiksi pornografi pada anak dengan berbagai sosialisasi yang dilakukan. Menurut Setiadi dan Kolip (2010, hlm. 17) mengemukakan bahwa "Keluarga adalah suatu institusi pengaruh penting dalam proses sosialisasi". Kepribadian seorang anak akan dipengaruhi oleh proses sosialisasi yang diberikan lingkungan terutama keluarga. Pitss (Sunarti, 2001, hlm. 5) menurutnya 'Seorang penganut faham structural-fungsional biasa memandang bahwa keluarga memiliki struktur yang dapat memenuhi kebutuhan secara fisik dan psikologis setiap anggotanya, serta sebagai upaya memelihara masyarakat yang lebih luas' setiap 
keluarga dan individu yang ada di dalamnya memiliki peran dan fungsi yang akan mempengaruhi masyarakat dan lingkungannya. Fungsionalsime structural merupakan suatu teori yang dapat menjelaskan fungsi keluarga untuk mengajarkan nilai dan norma yang berlaku di lingkungan mereka tinggal. Hal tersebut dijelaskan dalam kerangka A.G.I.L untuk menganalisi tindakan sosial. Terdapat fase Adaptation, Goal Attainment, Integration, dan Latten Pattern. Menurut Parson (Ritzer, 2014, hlm. 408) keempat fase tersebut merupakan impretatif fungsional. Hal ini untuk mencapai suatu kelestarian dalam sebuah sistem. Parson juga membuat skema AGIL untuk semua level dalam system teorinyaSebagai agen sosialisasi, keluarga membantu setiap anggota keluarganya terutama anak untuk melaksanakan proses penanaman nilai dan norma agar setiap anggota dalam keluarga bisa hidup dan diterima oleh masyarakat. Selain itu keluarga juga memiliki fungsi lain, menurut United Nation dalam $(\mathrm{H}$. Puspitawati, 2013) fungsi keluarga meliputi fungsi pengukuhan ikatan suami istri, prokreasi dan hubungan seksual, sosialisasi dan pendidikan anak, pemberian nama dan status, perawatan dasar anak, perlindungan anggota keluarga, rekreasi dan perawatan emosi, dan pertukaran barang dan jasa.

Setiap anggota keluarga harus saling melindungi baik secara fisik ataupun psikis. Keluarga juga memiki fungsi untuk mengontrol prilaku sosial dan seksual agar bisa menjaga nama baik keluarga. Mengontrol prilaku sosial dan seksual anak sangat dibutuhkan terutama saat ini, dengan kemudahan mengakses internet dan pengetahuan lainnya yang bisa didapatkan secara bebas. hal ini seperti yang dijelaskan oleh Mattensich (H. Puspitawati, 2013) 'bahwa keluarga memilik fungsi pemeliharaan fisik sosialisasi dan pendidikan, akuisisi anggota keluarga baru melalui prokreasi atau adopsi, kontrol perilaku sosial dan seksual, pemeliharaan moral keluarga dan dewasa melalui pembentukan pasangan seksual, dan melepaskan anggota keluarga dewasa'.

Keluarga perlu meningkatkan pengetahuan terutama dalam mecegah adiksi pornografi terhadap anak sebagai suatu upaya melindungi anak dari dampak buruk yang disebabkan oleh pornografi. Meskipun memang, untuk dapat mencegah adiksi pornografi terdapat berbagai kendala yang dapat mempengaruhi pencegahannya.

Faktor yang menyebabkan terjadinya adiksi pornografi pada anak usia Sekolah Dasar yaitu; tidak konsistennya aturan yang diberikan oleh orang tua, yang memiliki dampak anak menganggap remeh aturan yang telah dibuat.
Penyampaian pendidikan seks yang terlalu sempit, Memahami kembali mengenai pendidikan seks yang memiliki makna luas tidak hanya hubungan seksual, namun juga mengenai perkembangan manusia, penyadaran peran berdasarkan perintah Allah SWT, hubungan antar manusia adab berpakaian, masuk kamar orang tua; syarat sah seseorang beribadah; kemampuan personal tentang nilai, komunikasi, megosiasi dan pengambilan keputusan; perilaku seksual; kesehatan seksual; serta budaya dan masyarakat (Handayani, 2005, hlm 60). Kesalahan ketika memberikan pendidikan seks kepada anak akan memengaruhi penyimpangan yang dilakukan oleh anak, pendidikan seks yang salah dapat berpengaruh perkembangan berbagai bentuk penyimpangan seksual pada masa-masa berikutnya (Roqib, 2008, hlm. 4). Pola asuh otoriter dan permisif. Setiap prilaku dan pengasuhan yang diberikan akan berpengaruh terhadap pola komunikasi dalam suatu keluarga. Pengasuhan yang terlalu otoriter dapat menyebabkan seorang anak lebih tertutup terhadap keluarga sehingga untuk menyampaikan sesuatu anak tidak berani dan merasa terancam. Sedangkan pola asuh yang permisif, membuat anak berlaku dengan bebas sehingga akan kesulitan dalam memberikan aturan. Pola asuh otoriter merupakan jenis pengasuhan yang memaksakan kehendak orang tua. Pengasuhan jenis ini bersifat keras, karena orang tua menuntut anaknya agar patuh dengan segala keinginan orang tuanya. Interaksi yang dilakukan hanya dari arah orang tua saja sehingga jika anak melanggar apa yang sudah diperintahkan oleh orang tuanya akan memberikan dampak pada hukuman atau sanksi. Pola asuh otoriter dapat memberikan dampak negatif pada perkembangan psikologis anak (Rakhmawati, 2015, hlm. 5). Pengasuhan yang terlalu otoriter mengakibatkan anak menjadi tertutup dan tidak merasa bebas menyampaikan hal-hal yang seharusnya disampaikan karena anak akan berpikir bahwa apa yang disampaikannya akan menyebabkan amarah dari orang tuanya sehingga anak memilih untuk tidak menyampaikannya terutama mengenai hal-hal yang berhubungan dengan pornografi. Selain itu, pada keluarga lainnya adalah pola asuh permisif. Menurut Rakhmawati (2015, hlm 5) bahwa "Pola asuh dengan gaya persimisif merupakan pengasuhan yang memberikan kebebasan bagi setiap anak. Beberapa keluarga di Kelurahan Derwati Kecamatan Rancasari menggunakan pola asuh permisif, orang tua berpendapat bahwa anakanak yang masih usia Sekolah Dasar masih sangat hyperactive.

Penelitian ini mendapatkan temuan hilangnya keikutsertaan atau peran ayah dalam pengasuhan kepada anak-anaknya karena merasa 
bahwa ibu memiliki tanggung jawab besar untuk mengasuh anak-anaknya. Setiap anggota keluarga ayah, ibu dan anak memiliki tugas untuk memelihara keutuhan rumah tangga, membentuk kepribadian setiap anggota keluarga dengan akhlak yang mulia.

Untuk memeroleh keluarga yang kuat dan sehat diperlukan pemahaman mengenai ketahanan keluarga. Menurut Sunarti (Puspitawati dkk, 2013, hlm. 2) menjelaskan bahwa "Ketahanan keluarga dapat diukur dengan tiga hal yaitu ketahanan fisik, ketahanan sosial, dan ketahanan psikologis". Setiap keluarga tentu memiliki cita-cita dan tujuan untuk mempertahankan keluarganya secara utuh tanpa kekuarangan suatu apapun. Tercapainya ketahanan keluarga sebagai satu kesatuan yang membentuk sturktur dalam masyarakat, sangat diperlukan usaha memenuhi ketahanan fisik dan sosial dengan berusaha dengan memenuhi kebutuhannya berupa dangan pangan papan. Ketiga komponen tersebut merupakan hal penting yang harus ada untuk mencapai ketahanan keluarga yang kuat dan siap menghadapi tantangan dunia. Menjadi keluarga yang dapat menjaga ada anak dari dampak negatif perkembangan teknologi dan informasi terutama dari bahaya pornografi. Sehingga dapat menciptakan generasi-generasi yang sehat secara psikis dan fisiknya serta dapat menjadi manusia yang sesuai dengan nilai dan norma yang ada dalam kehidupannya.

\section{KESIMPULAN}

Berdasarkan pembahasan yang telah diuraikan mengenai peran keluarga dalam upaya pencegahan adiksi pornografi pada anak sangatlah penting, karena dalam keluarga terdapat berbagai fungsi dan peran penting dalam membentuk kepribadian anak yang lebih baik dan berkahlak mulia.

Melakukan sosialisasi untuk mencegah adiksi pornografi pada anak usia Sekolah Dasar dan mengenali faktor yang dapat menyebabkan terjadinya adiksi pornografi merupakan suatu bentuk upaya ketahanan keluarga pencegahan adiksi pornografi pada anak usia Sekolah Dasar dilakukan oleh keluarga di Keluarahan Derwati Kecamatan Rancasari untuk menghindari hal-hal yang berdampak negatif bagi anak. Suatu proses penanggulangan dilakukan dengan beberapa upaya. Hal yang dapat dilakukan pertama, membangun komunikasi dua arah (Antara orang tua dan anak). Merespon hal yang berkaitan dengan pornografi dengan mempersilahkan anak menyampaikan perasaan dan pikirannya. Hal terpenting dalam upaya ini adalah memberikan kepercayaan diri untuk berani menyampaikan halhal tersebut.

mempertegas kembali aturan yang berlaku di rumah dan di luar rumah berkaitan dengan penggunaan HP dan mengakses informasi. Kedua, upaya penanggulangan yang selanjutnya adalah dengan membantu anak dengan memberikan aturan kembali di rumah saat menggunakan HP dan mengakses informasi, bukan hanya pada anak yang berusia Sekolah Dasar, hal ini juga perlu diterapkan kepada anak lainnya. Selain itu, mempertegas aturan penggunaan HP ataupun perangkat lainnya yang memudahkan anak untuk mengakses informasi dibutuhkan alasan suatu aturan dibuat agar anak dapat lebih paham. Ketiga, yaitu dengan menambah pengetahuan mengenai era digital. Saat ini perkembangan teknologi dan informasi tidak dapat dibendung. Setiap orang tua hamper kewalahan karena merasa lambat mengikuti perkembangannya, bahkan para orang tua mengakui bahwa saat ini anak-anak lebih pandai dalam menggunakan gadget dan mengakses informasi. Keempat, mendukung tumbuh kembang dan kreatifitas anak untuk membentuk kerpibadian yang lebih baik. Setiap manusia diberikan keunikan yang berbedabeda oleh Allah SWT. Anak-anak yang berusia Sekolah Dasar memiliki berbagai macam kemampuan yang dapat dikembangkan. Selain itu kemampuan tersebut dapat membantu anak mengurangi paparan pornografi dari games ataupun media lainnya serta dapat mencegah anak terkurung dalam pikiran-pikiran mengenai gambar yang memiliki unsur pornografi. Kelima, adalah dengan memperkuat keimanan. Setiap manusia yang beriman meyakini bahwa setiap yang dilarang oleh Tuhannya merupakan perbuatan dosa dan jika melanggarnya akan berkahir dengan siksaan di dalam Neraka. Sebaliknya dengan segala sesuatu yang diperintahkan oleh Tuhan jika dilaksanakan akan mendapatkan pahala dan diberikan posisi di Syurga. Keluarga di Kelurahan Derwati Kecamatan Rancasari memilih kegitan yang meningkatkan pengetahuan iman dan Islam dengan mendorong anak mengikuti kegiatan di Taman Pendidikan Al-Quran (TPA) dan melakukan kegiatan rutin yang ada di lingkungan yaitu Magrib Mengaji. Memberikan kesibukan kepada anak dengan hal-hal yang baik dapat membantu ia terhindar dari bahaya pornografi. 


\section{REFERENSI}

\section{Buku}

Handayani, Sarah. (2005). Bekal Pendidikan

Seks Buat Si Buyung. Jakarta: Majalah Ummi

Kastlemen, B, Mark. (2016). The New Drug of The New Millenium. Bekasi: Yayasan Kita dan Buah Hati

Reiss dan Halstead. (2006). Pendidikan Seks Bagi Remaja: dari Prinsip ke Praktik. Yogyakarta: Alenia Press

Ritzer, George. (2014). Teori Sosiologi (dari sosiologi klasik sampai perkembangan terakhir postmodern). Jakarta: Pustaka Pelajar

Setiadi,M,E \& Kolip, U. (2010). Pengantar Sosiologi. Jakarta: Prenada Media Group

Sunarti \& Suhardi. S. (2009). Sosiologi 2. Jakarta: Pusat Perbukuan

\section{Jurnal}

Kartinah, E. (2011). Pornografi , Candu Perusak Otak. Media Indonesia, (April), 2011.

Puspitawati, S.(2013). Konsep dan Teori Keluarga. Departemen Ilmu Keluarga dan Konsumen Fakultas Ekologi Manusia- Institut Pertanian Bogor
Indonesia . PT IPB Press . Bogor . Komunikasi Pembangunan, (Zeitlin 1995), 1-16.

Rakhmawati, I. (2015). Peran Keluarga dalam Pengasuhan Anak. Jurnalbimbingan Konseling Isla, 6(1), $1-18$.

https://doi.org/10.21043/kr.v6i1.1037

Roqib, M. (2008). Pendidikan Seks pada Anak Usia Dini. Jurnal Pemikiran Alternatif Pendidikan, 13(2), 271-286. Retrieved from http://ejournal.iainpurwokerto.ac.id/ind ex.php/insania/article/view/298

\section{Internet}

Lokadata (2012). Jumlah Penduduk dan Anak Usia 0-17 Tahun. [online]. Tersedia: https://lokadata.beritagar.id/chart/previ ew/jumlah-penduduk-dan-anak-usia-017-tahun-juta-jiwa-2000-20151511234597 [1 Maret 2018] Yayasan Kita dan Buah Hati. (2017). Panduan Melindungi Anak dari Konten Pornografi. [online]. Tersedia: http://kitadanbuahhati.co/panduanmelindungi-anak-dari-kontenpornografi-gratis/ [21 Februari 2018] 